\title{
Spatial and seasonal variations of the snow chemistry at the central Filchner-Ronne Ice Shelf, Antarctica
}

\author{
Andreas Minikin, Dietmar Wagenbach, \\ Instilut für Umwellphysik, Universiläl Heidelberg, D-69120 Heidelberg, Germany \\ WOLFGANG GRAF, \\ GSF-Forschungszentrum für Cimaelt und Gesundheit, Instilul für Hydrologie, D-85758 Oberscheissheim, Germany \\ JOSEF KIPFSTUHL \\ Alfred-W'egener-Institut für Polar- und Meeresforschung, D-27515 Bremerhaven, Germany
}

\begin{abstract}
The chemical stratigraphy of the surface firn of the central FilchnerRonne Ice Shelf was determined in conjunction with stable isotopes from shallow firn cores and snow-pit samples collected at 15 widely distributed sites, and covering a time period of at least 20 years. The chemical analysis included ECM profiling and the determination of chloride, non-sea-salt (nss) sulphate, methanesulphonatc (MSA), nitrate and, partly, sodium and bromide. Throughout the investigated area, winter time nss sulphate levels are found to be substantially negative, indicating that the sulphate to sodium ratio in airborne sea-salt particles is depleted by a factor of 5 , approximately, in relation to the bulk sea-water ratio. While winter firn layers appear to be marked by episodic events of large sea-salt inputs, pronounced annual cycles with maxima in summer firn layers arc commonly observed for the ECM signal and for nss sulphate, nitrate and MSA at all sites. For MSA, however, this phase relation is almost reversed for depths greater than $34 \mathrm{~m}$.

The mean impurity levels consistently are strongly depleted with increasing distance from the ice edge by about $30 \% / 100 \mathrm{~km}$ for sea salt, $25 \% / 100 \mathrm{~km}$ for MSA and only $10 \% / 100 \mathrm{~km}$ for nss sulphate. However, no substantial trend is observed for nitrate. It is concluded, therefore, that the sca-salt and the biogenic sulphur compounds deposited on the Filchner-Ronne Ice Shelf mainly originate from the adjacent Weddell Sea.

Further important implications of the continental effects are: (a) an atmospheric residence time of nss sulphate apparently exceeding that of MSA probably due to the supplementary sulphate production on the ice shelf from biogenic $\mathrm{SO}_{2}$, and (b) a substantial limitation of the potential of deep icc cores already drilled on the FilchnerRonne Ice Shelf in extracting reliable net temporal changes of sea-salt and biogenic sulphur species.
\end{abstract}

\section{INTRODUCTION}

In contrast to central Antarctica, only few glaciochemical records are available from Antarctic ice shelves. Due to their simple topography, the relatively high snow-accumulation rate and the immediate access to the occan, these snow fields are expected to bc particularly useful in deriving high-resolution records of coastal Antarctic snow chemistry. Addressing the question of the biogeochemical cycles of nitrogen and sulphur components, representative deposition fluxes of these species into the Southern Ocean, which are difficult to access, may be quantified by determining the deposition fluxes on to the adjacent icc shelves.

The Filchner-Ronne Ice Shelf, extending about $500 \mathrm{~km}$ from the coast to the margin of the Antarctic inland icc, is of particular importance in this context, because it lies adjacent to the biologically highly productive Weddell Sea. With the aim of evaluating the dynamics and mass balance of the Filchner-Ronne Ice Shelf, numerous glaciological studies in the framework of the international Filchner-Ronne Ice Shelf Programme. have been undertaken there.

During several German glaciological surveys in the years 1985-92, an extensive series of snow-pit samples and shallow firn cores has been recovered from the central Filchner-Ronne Icc Shclf (Graf and others, 1988, 1991; Oerter and others, 1992b). Here, we present an overvicw of the results of the chemical analyses of 14 firn cores, each covering a time period in the order of 20 ycars, and five snow pits for 15 different sampling sites. This detailed data base appears to be appropriate for determining the spatial significance of any trends in the chemical composition of the surface firn. This information is directly necessary for the interpretation in terms of temporal changes of the chemical depth profiles of two 
intermediate-depth ice cores recovered on the FilchnerRonne Ice Shelf.

Therefore, emphasis will be on the spatial distribution and particularly on the continental effects of the mean concentrations and deposition fluxes of sea salt, nitrate and the biogenic sulphur compounds. In addition, the seasonality of these chemical trace spccies, which are used in combination with the stableisotope stratigraphy to derive precise and temporal representative snow-accum-ulation rates, will be briefly outlined. Detailed results of the isotopic analyses have been given by Graf and others (1994) and specific aspects of the isotopic and chemical information on the two Berkner Island ice domes have been outlined by Wagenbach and others (1994).

\section{SAMPLING}

The chemical analyses reported here were undertaken on snow-pit samples and shallow firn cores collccted during several German glaciological surveys on the Filchner-Ronne Ice Shelf during the summer field campaigns 1985-86, 1989-90 and 1991-92. An overview of the various drilling sites on both ice shelves is shown on the map in Figure 1. All firn cores were transported back in a frozen state to the AlfredWegener-Institut für Polar-und Meeresforschung in Bremerhaven, where the core samples were split into two parts: one was prepared for high depth resolution analysis of stable isotopes of water by the GSF in München-Neuherberg, and the second one was used for chemical analysis at the Institut für Umweltphysik in Heidelberg. The firn cores from the drilling locations marked in Figure 1 by solid circles were prepared for high depth resolution $(3-5 \mathrm{~cm})$ analysis to resolve the seasonality in the chemical stratigraphy. Cores from locations marked by open circles were analysed at lower depth resolution of $20-30 \mathrm{~cm}$ only.

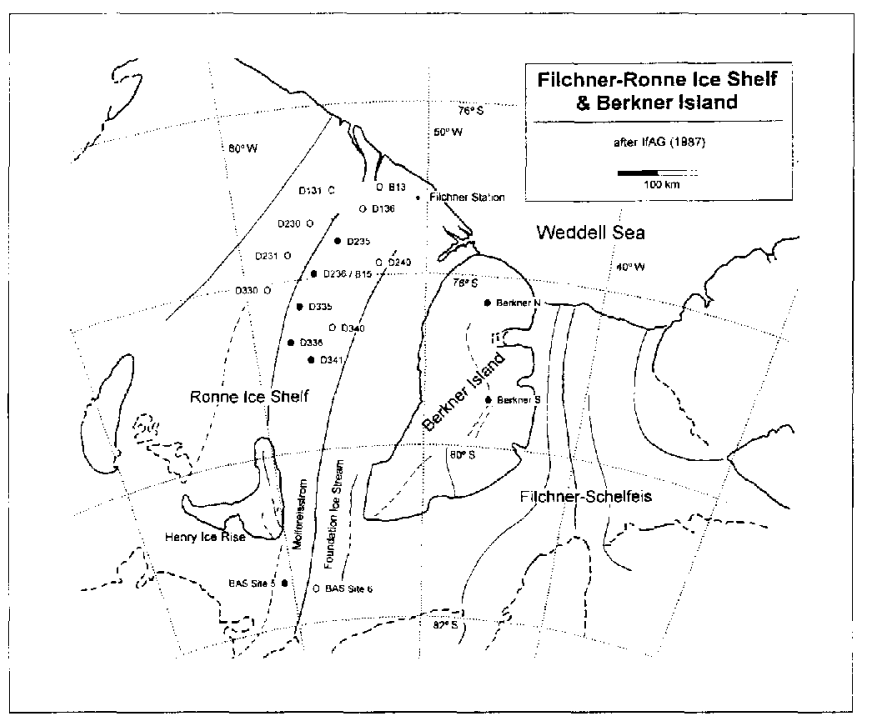

Fig. 1. Map of the Filchner-Ronne lce, Shelf after If $A G$ (1987). Solid circles are assigned lo fin cores analysed at high depth resolution $(3-5 \mathrm{~cm})$, open circles refer to firn cores analysed in lower depth resolution $(20-30 \mathrm{~cm})$.

\section{ANALYTIGAL PROGEDURES}

Outer parts were removed carefully from the snow and firn core samples by contamination-free handling procedures in a cold laboratory. The resulting samples were melted in pre-cleaned polyethylene bags.

All ion chromatographic measurements were made using a Dionex 4500i chromatograph equipped with Dionex columns and chemical suppression. For most samples, a gradient technique on a Dionex AS4A column with $\mathrm{NaOH}$ as eluent was used to analyse all anions in one run (methanesulphonate, chloride, bromide, nitrate and sulphate). Sodium was analysed only on part of all firn cores either by ion chromatography, using a Dionex CS10 column, or by flame atomic emission spectrometry. Excluding bromide, the detection limit for the species with lowest concentrations, methanesulphonate, is about $0.5 \mathrm{ppb}$ for a sample volume of $1000 \mu \mathrm{l}$ which is fully appropriate for most of the snow samples. Lower concentrated samples were partly analysed using a preconcentration column and $5 \mathrm{ml}$ sample volume. The analytical precision for all ion measurements reported here is typically $5 \%$.

Prior to the firn-core sub-sampling for detailed chemical analyses, continuous d.c. conductivity profiles were recorded in the cold laboratory following the method introduced by Hammer (1980) (ECM method). A plane surface is prepared on the firn core with a microtome knife. Along this surface, two carbon-brush electrodes are moved with constant velocity applying a voltage of $1500 \mathrm{~V}$. In Antarctic ice cores, the resulting ECM signal has been interpreted as an indicator of strong acid concentration (Legrand and others, 1987; Moore and others, 1992).

\section{CHEMIGAL CHARACTERIZATION OF THE FILCHNER-RONNE ICE SHELF}

'Table l summarizes the mean concentrations of methanesulphonic acid (hereafter denoted as MSA), non-sea-salt sulphate (nss sulphate), chloride and nitrate for the sampling sites on the central Filchner-Ronne Ice Shelf. For consistency in the evaluation of the chemical depth profiles being present in either high or low depth resolution, all values are calculated as mass weighted, arithmetic means.

Generally, chloride, nitrate and nss-sulphate concentrations fall into ranges which are consistent with chemical data obtained from other Antarctic ice shelves, namely the Ross Ice Shelf (Hcrron and Langway, 1979; Herron, 1982), Riiser-Larsenisen (Gjessing, 1984; Ncubauer and Heumann, 1988) and Ekstromisen (Moser, 1991). Compared to the chemical composition of the Antarctic inland ice (Clausen and Iangway, 1989), the level of sca salt on the ice shelves is about one order of magnitude higher and that of nss sulphate is only slightly higher, whereas nitrate concentrations do not differ significantly in both regimes.

Typical MSA concentrations for the Filchner-Ronne Ice Shelf are in the range $10-18 \mathrm{ppb}$, which is slightly higher than the $612 \mathrm{ppb}$ observed at Ekstrømisen (Minikin, 1989). Other ice-shelf data for MSA are to 
Table 1. Mean concentrations of aerosol species and snow-accumulation rates for firn-core and snow-pit samples collected on the Filchner Ronne Ice Shelf. The dates refer to the chemically analysed depth intervals

\begin{tabular}{|c|c|c|c|c|c|c|}
\hline \multirow[t]{2}{*}{ Location } & \multirow{2}{*}{$\begin{array}{l}\text { Period } \\
\text { covered }\end{array}$} & \multirow{2}{*}{$\begin{array}{l}\underset{\text { Accumulation }}{\text { rate }^{\ddagger}} \\
\mathrm{kg} \mathrm{m}{ }^{-2} \mathrm{a}^{-1}\end{array}$} & \multicolumn{4}{|c|}{ Mean concentrations } \\
\hline & & & \multicolumn{4}{|c|}{$\mathrm{ppb}$} \\
\hline $\mathrm{BC} 90 / \mathrm{B} 13$ (snow pit) & $1989-87$ & 330 & 19.0 & 95.0 & 871 & 48.0 \\
\hline D 131 & $1989-66$ & 201 & 17.0 & 88.7 & 797 & 37.7 \\
\hline D136 & $1989-62$ & 189 & 15.1 & 90.8 & 792 & 29.6 \\
\hline D230 & $1989-67$ & 199 & 14.1 & 74.7 & 484 & 36.4 \\
\hline D23j & $1987-68$ & 184 & 14.7 & 81.3 & 663 & 44.1 \\
\hline D235 (snow pit) & $1989-87$ & 270 & 17.0 & 58.0 & 681 & 50.0 \\
\hline $\mathrm{D} 240^{*}$ & $1982-75$ & 196 & 18.0 & 81.0 & 648 & 41.0 \\
\hline $\mathrm{D} 236 / \mathrm{B} 15$ & $1989-65$ & 166 & 16.6 & 88.0 & 509 & 45.4 \\
\hline BC92/D236 (snow pit) & $1991-87$ & 232 & 11.2 & 67.9 & 461 & 67.3 \\
\hline $\mathrm{D} 231$ & $1987-65$ & 185 & 14.4 & 59.0 & 410 & 37.7 \\
\hline D335 & $1987-66$ & 170 & 15.4 & 80.0 & 393 & 57.9 \\
\hline D335 (snow pit) & $1989-87$ & 240 & 13.0 & 70.0 & 305 & 71.0 \\
\hline D330 & $1987-66$ & 176 & 10.0 & 74.6 & 385 & 36.1 \\
\hline $\mathrm{D} 340^{*}$ & $1982 \cdot 68$ & 155 & 12.0 & 74.0 & 357 & 49.0 \\
\hline D336 & $1981-64$ & 156 & 11.6 & 78.9 & 401 & 50.5 \\
\hline D341* & $1982-56$ & 137 & & 69.0 & 355 & 49.0 \\
\hline $\mathrm{D} 341^{\dagger}$ & $1982 \cdot 56$ & 137 & 8.0 & 58.0 & 317 & 52.0 \\
\hline BAS site 5 & $1989-39$ & 92 & 3.7 & 63.0 & 183 & 51.3 \\
\hline BAS site 6 & $1989-36$ & 89 & 4.8 & 59.9 & 193 & 71.1 \\
\hline
\end{tabular}

* Chloride, nitrate and nss-sulphate concentrations from Moser (1991).

One bulk sample prepared from remnant liquid of the high-resolution samples.

$\stackrel{t}{\dagger}$ Dating and snow-accumulation rates, after Graf and others (1994).

our knowledge not yet available. Concentrations on the Antarctic plateau appear to be slightly lower: for instance, a range of 7-13 ppb was given by Legrand and others (1992) for a South Pole firn core and lower levels were measured in the Vostok and Dome $\mathrm{C}$ ice cores (Legrand and others, 1991).

\section{Sea-salt species}

The chloride to sodium ratio was determined at high depth resolution only for the sampling sites D236 and D335. This ratio is slightly higher in summer layers than the sea-water ratio of 1.80 (Wilson, 1975), suggesting additional deposition of $\mathrm{HCl}$ during this season (Legrand and Delmas, 1988). The mean chloride to sodium mass ratio for both positions is 2.0 . To treat all sites consistently, we chose chloride as the sea-salt reference element.

Bromide concentrations were determined incidentally when a gradient technique was used for anion analyses. Against the assumption of finding the winter sea-salt peaks associated with enhanced bromide concentrations according to the sea-water proportion of bromide, in the near-surface layers we generally found a weak seasonal pattern with higher concentrations in summer. These summer values are in the order of $1-3 \mathrm{ppb}$ and essentially in excess of the contribution expected from sea salt. This observation may be partly explained by the deposition of gaseous $\mathrm{HBr}$ in an analogous way to HCl. However, bromide seems to be severely affected by a postdepositional loss process because the concentrations fall almost always below our detection limit of about $0.5 \mathrm{ppb}$ below 2 or $3 \mathrm{~m}$ depth. Therefore, no further use of the bromide data will be made here.

\section{nss-sulphate calculation}

Using sodium (or chloride) as a reference element for seá salt, the nss-sulphate concentrations are commonly calculated from the total sulphate and the sea-salt concentration according to Equation (1):

$$
\left[\mathrm{nss} \mathrm{SO}_{4}{ }^{2-}\right]=\left[\text { total } \mathrm{SO}_{4}{ }^{2-}\right]-k\left[\mathrm{Na}^{+}\right]
$$

with

$$
k=\left(\frac{\left[\mathrm{SO}_{4}^{2 \cdots}\right]}{\left[\mathrm{Na}^{+}\right]}\right)_{\text {sca water }}
$$

However, if the sea-water mass ratio of sulphate to sodium of 0.252 (Wilson, 1975), here denoted as $k$, is used in Equation (1), significantly negative nss-sulphate 
concentrations occur in almost all winter firn layers at each sampling site of the Filchner-Ronne Icc Shelf. This is also true at site D336, which is located about $300 \mathrm{~km}$ away from the coast. This phenomenon is also observed in other coastal Antarctic regions, as for example in firn cores from Riiser-Larsenisen (Gjessing, 1989) and the Antarctic Peninsula (Mulvaney and others, 1992) or in aerosols sampled at Neumayer Station (Wagenbach and others, 1988). Apparently, sulphate must be depleted, at least in winter, in airborne sca-salt particles, leading to an important underestimation of nss sulphate using Equation (1). The process responsible for the sulphate depletion is still not clear but we expect this to happen because of a chemical fractionation during the production of sea-salt - particles under conditions of low air tempcratures.

To compensate for the assumed sulphate fractionation, an empirical approach to the true sulphate to sodium ratio in the local sea-salt acrosol has been established by selecting all winter samples, for which the true nss-sulphate level can be expected to be relatively low and constant (unpublished work of A. Minikin and D. Wagenbach). Variation of $k$ in Equation (1) to give a minimal correlation between (formally) calculated nss sulphate and sodium among these samples then leads to a corrected $k^{*}$,

$$
k^{*}=\left(\frac{\left[\mathrm{SO}_{4}^{2-}\right]}{\left[\mathrm{Na}^{+}\right]}\right)_{\text {sea-salt aerosol }}
$$

which is considerably lower than $k$ but surprisingly constant for all drilling locations analysed here in high depth resolution (Table 2). The apparent sulphate depletion, at least in the winter sca-salt particles, is found to be about a factor of 5. Considering the different sampling processes involved, this value agrees fairly well with the depletion factor of about 4 deduced from the aerosol record at Neumayer Station.

Subsequently, the term nss sulphate refers exclusively to the corrected nss-sulphate concentrations as calculated by the sodium to sulphate ratios, $k^{*}$, given in Table 2 (for sites not mentioned in Table 2 an arithmetic mean of 0.049 is uscd for $k^{*}$ ). Although there is no clear evidence for the sulphate-fractionation effect in the sea-salt

Table 2. Estimated sulphate to sodium mass ratios in seasalt aerosol $\left(k^{*}\right)$ at Veumayer Station and at zarious locations on the Filchner-Ronne Ice Shelf

$$
\text { Sample type Localion } \quad k^{*}
$$

Aerosol samples 1983-91

Neumayer Station

0.058

Firn cores from

$\mathrm{D} 235 \quad 0.048$

Filchner-Ronne Ice Shelf

$\mathrm{D} 236$

0.043

D335

0.050

D341

0.049

D336

0.056

Bulk sea water particles to occur also in summer, we have omitted a seasonal dependence of $k^{*}$. Therefore, the summer nsssulphate concentrations may be systematically overestimated. Because of generally lower sea-salt and maximum nss-sulphate concentrations in the summer firn layers, we estimate this effect to be of the order of $10 \%$ or even lower.

In any case, if sea-salt concentrations reach or even exceed 1 ppm, which may still be the case at distances of about $100 \mathrm{~km}$ from the coast, nss-sulphate values measured in bulk or especially in winter samples will bo considerably underestimated if the sulphate-fractionation effect is not accounted for.

\section{SEASONALITY OF GHEMICAL SPECIES}

Serving as a typical example for the firn cores analysed in high depth resolution, the chemical, ECM and $\delta \mathrm{D}$ profiles of site D235 are presented in Figure 2. The ECM and the chemical records were slightly low-pass filtcred to emphasize the main features. As is the case at sites D236, D335, D336 and D34l not shown here) and also at the Berkner Island ice domes, the ECM, nss-sulphatc,

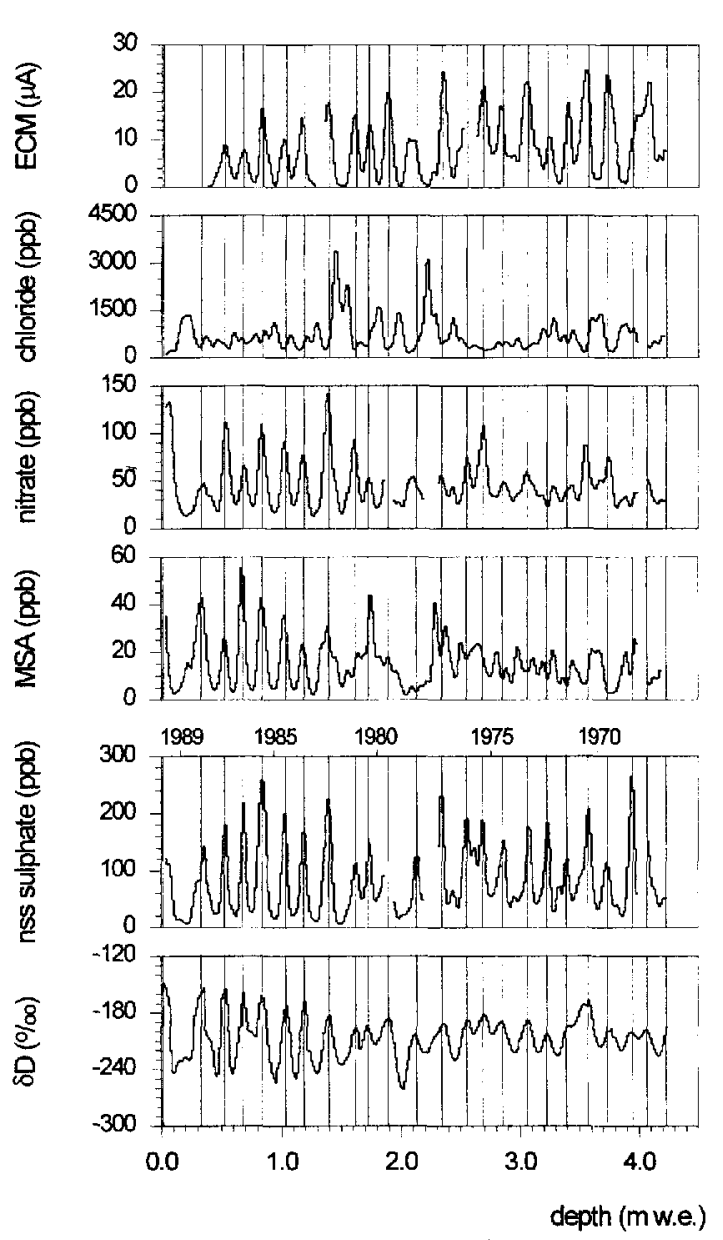

Fig. 2. Profiles of ECM, chemical species and $\delta D$ for the firn core drilled at site D235. The depth scale is given in water equivalent (w.e.). All records are transformed to equidistant depih intervals (1.5 cmw.e.). The ECM and chemical records are sightly low-pass filtered with a ficepoinl Ciaussian filter. Summer horizons according to the year-to-year dating are marked with vertical bars. 
nitrate and $\delta \mathbf{D}$ profiles reveal a clear annual layering of the firn. Among the chemical records, the nss-sulphate particularly shows most univocal seasonal variations with summer maxima lying very well in phase with the isotopic summer maxima. Therefore, the precise dating of all the firn cores was established by a combination of the isotopic and the nss-sulphate stratigraphy for details see Graf and others, 1994).

Figure 3 shows for site D235, which again is presented as a typical example for all the sites investigated, the calculated mean annual cycles of chloride, nitrate, MSA and nss sulphate. To obtain these mean seasonal patterns, the periods January-June and July-December were. defined in each individual annual layer according to the year-by-year dating mentioned above and then divided into evenly spaced time intervals for subsequent averaging over all selected years. To reveal possible ageing and/or depth effects in the seasonal pattcrn of these species, the averaging of individual years was carricd out for two depth intervals: the upper containing the first 7 years of accumulation as counted from the surface (1983-89), and the lower containing a 7 year period close to the bottom of the firn core $(1970-76)$.

\section{Chloride}

Generally, all chloride depth profiles are characterized by episodic sea-salt events which show up predominantly in the winter firn layers. This seasonal pattern is illustrated in Figure 3 by the mean annual cycle at site D235, showing the chloride minimum in January and the maximum around June-July with no significant difference between both depth intervals. The sea-salt concen-

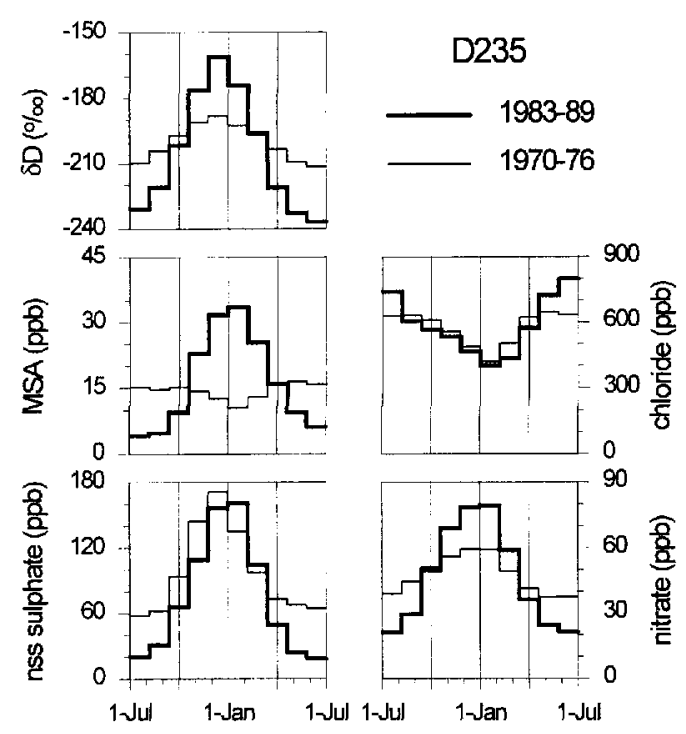

Fig. 3. Mean annual cycles of $8 D$, chloride, nitrate, MSA and nss sulphate for the firn core drilled at site D235. The thick line is assigned to a near-surface depth interval (corresponding to the years 1989-83) and the thin line to a lower depth interval (1976-70). Note that the apparent higher nss-sulphate base line in the lower core section (which is not observed at the other drill sites) may arise from an averaging effect or a systematic error in the correction for the winler-lime nss sulphate. tration in the firn, therefore, does not directly follow the annual cycle of sea-ice cover which is generally at its minimum around February (Zwally, 1984). As a consequence, sea-salt particles deposited on the Filchner-Ronne Ice Shelf within the winter accumulation must have been transported over relatively long distances (if not derived from local polynas). The sea-salt signal, therefore, appears to be connected more closely to the large-scale storm activity over the Southern Ocean rather than to the actual sea-ice coverage.

\section{Nitrate}

In all firn cores, nitrate shows a quite distinct seasonal pattern with a maximum in summer (DecemberJanuary) and minimum in winter (Fig. 3) A comparison of the nitrate firn records with the Neumayer Station acrosol record, howcver, reveals an important differcnce for the timing of the absolute nitrate maximum: nitrate sampled by the high-volume aerosol filters peaks regularly during late spring-early summer with secondary maxima in late winter and early spring (Wagenbach and others, 1988). These secondary maxima are, however, observed only in some years in the firn records. Part of the discrepancies between the seasonal aerosol and the firn nitrate cycles may simply be explained by the much lower time resolution achicved in the firn records. In explaining this phenomenon more rigorously, post-depositional changes of nitrate in surface snow and the mobilization of $\mathrm{HNO}_{3}$ from the acrosol filters during summer by biogenic sulphuric acid should also be considered.

Unlike sea salt or nss sulphate, the amplitude of the annual nitrate cycle is considerably dampened with increasing depth by roughly a factor of 2 in all firn cores. This effect is only partly attributed to a down-core reduction of the depth resolution in relation to the annuallayer thickness. Also, possible small phase shifts between the chemical and the isotopic profiles due to sub-sampling errors, which would for example also influence the nsssulphate peaks, cannot explain this smoothing effect. The broadening of the nitrate peaks may be driven by gasphase $\mathrm{HNO}_{3}$ diffusion within the porous firn layer during snow metamorphosis. However, by comparing the nitrate levels in the upper and lower depth intervals of all firn cores, no significant net loss of nitrate could be observed.

\section{nss sulphate and MSA}

The nss sulphate and, restricted to the ncar-surface layers, also the MSA profiles show a very pronounced annual cycle with peak-to-base line ratios of up to 10 . Within the limitations given by the depth resolution of approximately ten samples per year, the summer peak coincides with the maximum of the stablc-isotope content. It is here defined to mark the beginning of each year, which is in agreement with our findings at Neumayer Station where the aerosol record from 1983 to 1992 shows nss-sulphate air concentrations consistently peaking in the first half of January (Wagenbach and others, 1988).

The direct aerosol measurements at Neumayer Station show a basically congruent annual cycle of MSA and nss sulphate (unpublished data of A. Minikin and D. Wagenbach). This is indeed always the case for the topmost firn 
layers (for site D235, see Figures 2 and 3 ) but for depths greater than 3-4 $\mathrm{m}$ the phase relation to the nss-sulphate record is almost reversed with MSA peaks frequently occurring in winter firn layers. However, the ovcrall MSA to nss-sulphate ratios do not differ significantly in the selected upper and lower depth intervals. MSA winter peaks were previously observed by Mulvaney and others (1992) in the Dolleman Island ice core and they attributed this phenomenon to a post-depositional migration process which is still unclear.

\section{ECM}

A methodically important result is the suitability of ECM profiling at the Filchner-Ronne Ice Shelf for preliminary dating purposes even in the low-density firn. It is obvious that the ECM signal is correlated to the summer maxima of the strong acid contributors nss sulphate $\left(\mathrm{H}_{2} \mathrm{SO}_{4}\right)$, nitrate $\left(\mathrm{HNO}_{3}\right)$ and, partly, MSA and $\mathrm{HCl}$. Furthermore, the sea-salt peaks, frequently occurring in winter layers, are always accompanied by a near-zero ECM current. The combination of both effects leads to the relatively clear annual variation of the ECM signal. Only the ECM profiles of the southernmost drilling sites, BAS sites 5 and 6 , reveal no clear seasonal pattern but this is in accordance with the blurred isotopic stratigraphy found there.

\section{SPATIAL VARIATIONS OF THE SNOW CHEMISTRY}

In order to investigate the spatial trends of the mean concentrations, the sampling sites were combined into three sets, each associated with a different flowline of the ice shelf (sec map in Fig. 1): first, the B13-B15 flowline extending upstream from the B13 site to Möllereisstrom including the sites D136, D235, D236 (B15), D335, D336 and BAS site 5; secondly, the so-called western flowline (D131, D230, D231 and D330), and thirdly, the eastern nowline (D240, D340, D341 and, again, BAS site 5). From the data given in Figure 4, no significant trend of the mean concentrations of the chemical components in a northwest-southeast direction or parallel to the coast can be deduced. Slightly lower concentration levels generally observed on the western flowline are possibly due to the $10 \%$ higher accumulation rates there.

However, going southward, parallel to the flowlines, the chemical firn composition changes systematically with increasing distance from the ice edgc. As shown in Figure 4 , these changes are consistent within all three data sets. The chloride concentrations drop from about $900 \mathrm{ppb} 50 \mathrm{~km}$ inland from the ice edge down to $200 \mathrm{ppb}$ at the southernmost sites close to the grounding line. This corresponds to a decrease of about $30 \% / 100 \mathrm{~km}$, if the data for the B13-B15 flowline are parameterized by an exponential fit. MSA also exhibits a quite distinct decrease of about $25 \% / 100 \mathrm{~km}$, whereas the nss-sulphate concentration decreases more gradually by about $10 \% / 100 \mathrm{~km}$. Nitrate, on the other hand, reveals an almost opposite pattern: the concentrations appear to show a weak tendency of increasing values towards more continental positions on the ice shelf.

A special situation for the sea-salt (chloride) gradient

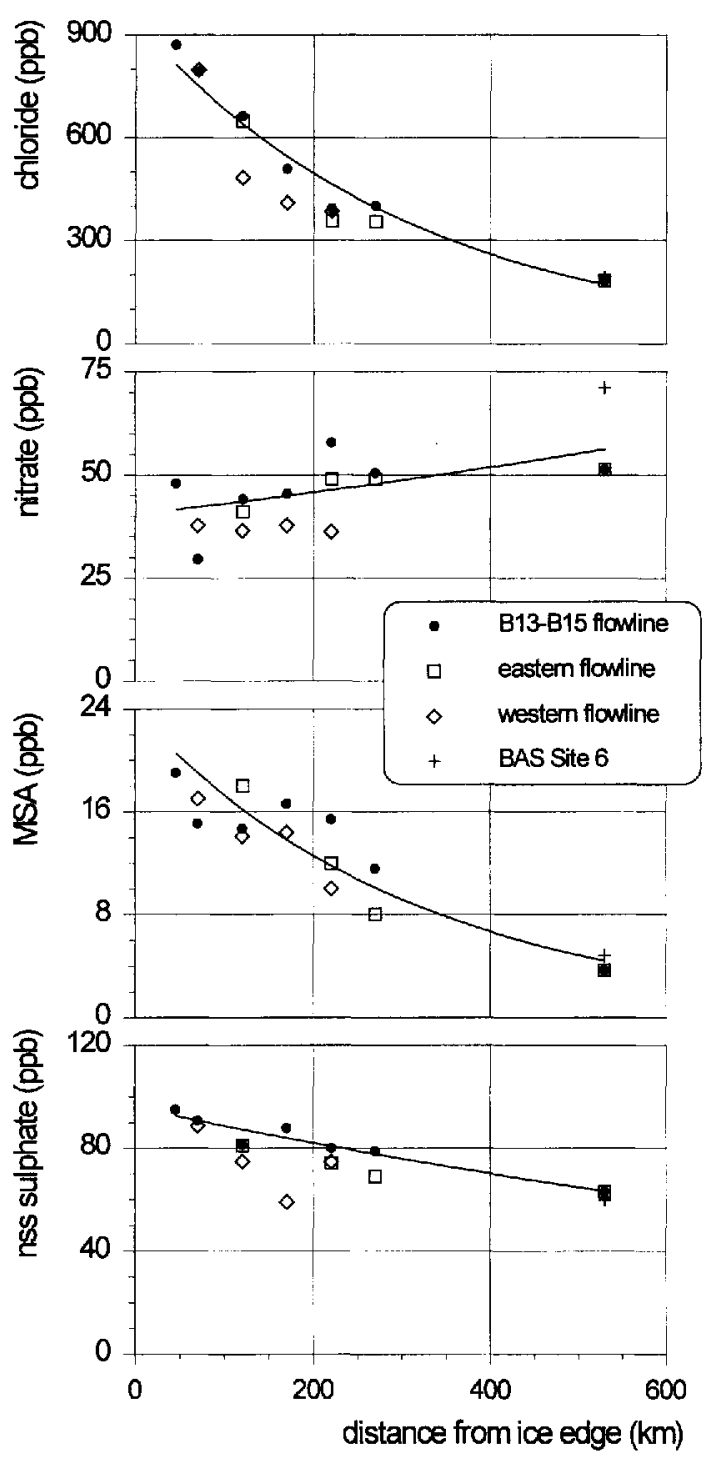

Fig. 4. Spatial trends of chloride, nitrate, MSA and nsssulphate concentrations on the central Filchner-Ronne Ice Shelf. The data points are divided into three sets representing different flowlines on the ice-shelf surface (for details see text). Snow-pit data are not included. The exponential fils were calculated for the data assigned to the B13-B15 flowline.

is encountered in the direct vicinity of the ice edge, where much highcr sea-salt concentrations than indicated by the general trend in Figure 4 were observed (Görlach and others, 1985). Also, at Neumayer Station on Ekstromisen, at a distance of $9 \mathrm{~km}$ from the coast, firncore analysis revealed a mean chloride concentration of $40 \mathrm{ppm}$. Such high concentrations are caused by dry deposition of locally produced, large sca-salt particles, as can be inferred from the much lower mean chloride concentration of $1.5 \mathrm{ppm}$ in fresh snow collected regularly at the same site (Trefzer, 1992).

There are two important questions connected with the continental effects described above:

1. Which information on the main source and on the transport history of the chemical species can be deduced from the systematic changes observed?

2. What are the consequences to be considered in 
evaluating net temporal changes from chemical depth profiles of intermediate-depth ice cores drilled on the central Filchner-Ronnc Icc Shelf?

\section{Sources and transport of chemical species}

The continental effects directly reflect the marine source region of the sea-salt and the biogenic sulphur aerosol components in contrast to nitrate, where at lcast an advection through the upper troposphere is to be expected (Legrand and Kirchner, 1990). From direct aerosol measurements of nss sulphate and MSA at coastal Antarctic stations, it has already been established that nss sulphate is controlled by the biogenic emission of dimethyl sulphide from the Southern Ocean surrounding Antarctica (Wagenbach and others, 1988; Prospero and others, 1991; Savoie and others, 1992). In particular, the existence of the continental effects of the biogenic sulphur species deposited on the Filchner-Ronne Ice Shelf confirms that the main source region of these species is the adjaccnt Weddell Sca area. 'This is plausible, because at least the front and central parts of the Filchner-Ronne Ice Shelf are directly influenced by marine rather than continental air masses as experienced from the weather conditions in the field and indicated by modelling of the katabatic wind regime over the Antarctic continent (Parish and Bromwich, 1991).

Assuming a first-order removal process being responsible for the observed ncar-exponential decrease of the chloride, MSA and nss-sulphate concentrations leads to relative residence times of these aerosol species against wet deposition on the ice shelf in the order of $1,1.3$ and 2, respectively (as calculated from exponential fits to all data). Note that, on an ice shelf, the continental effects are not biased by any orographical effects. Surprisingly, the relative residence time of the large-particle sea-salt aerosol is thereby comparable to that of MSA, which is a secondary aerosol component and hence associated with sub-micron particles (Pszenny and others, 1989). This indicates, that the sea-salt aerosol deposited in the central Filchner-Ronne Ice Shelf is relatively aged and not primarily of local origin.

The difference in the relative removal rates of MSA and nss sulphate may be a consequence of their different reaction pathways: according to current knowledge, both components constitute the end products in the DMS oxidation scheme but, in contrast to MSA, biogenic nss sulphate is believed to be formed via the gaseous precursor $\mathrm{SO}_{2}$, whose atmospheric lifelime is comparable to that of aerosol particles (Andreae, 1986; Berresheim, 1987). The $\mathrm{SO}_{2}$ may, therefore, be subject to considerable transport over the ice shelf before it is oxidized to sulphate. Compared to MSA, this may lead to the weaker continental effect of nss sulphate observed at the Filchner-Ronne Ice Shelf.

The geochemically relevant deposition fluxes of the acrosol spccics investigated and shown in Figure 5 were calculated from the mean concentrations and the accumulation rates given in Table 1 . Due to the systematic decrcase of the accumulation rates along the flowline, the spatial gradients for the sea-salt, nss-sulphate and MSA deposition fluxes are enhanced when compared to the corresponding concentrations. Again, the mean

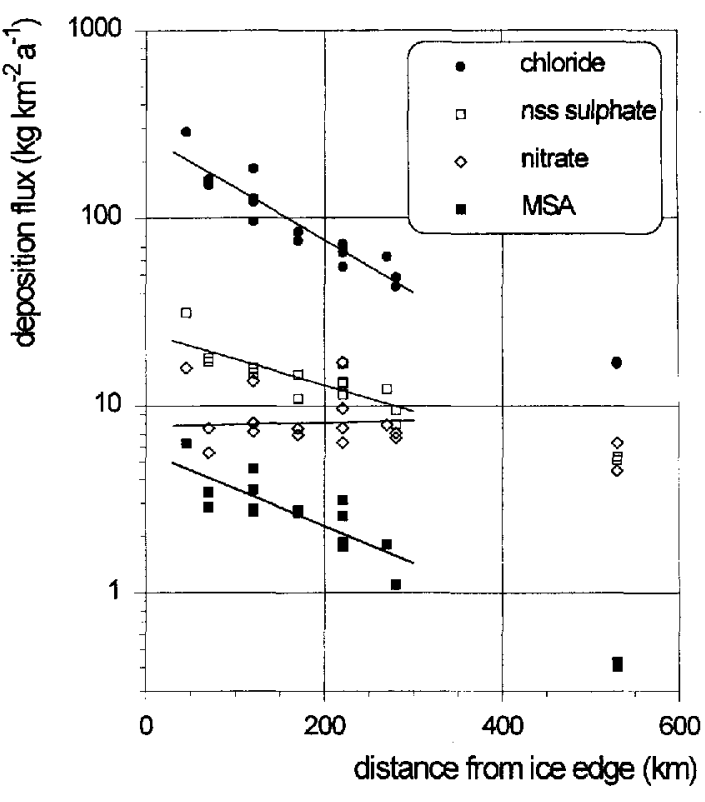

Fig. 5. Spatial trends of chloride, nitrate, MSA and nsssulphate deposition fluxes on the central Filchner-Ronne Ice Shelf.

deposition fluxes can be well described by the exponential fits shown in Figure 5. However, no significant trend is observed for the nitrate-deposition fluxes.

The chloride-deposition fluxes in the southernmost parts of the ice shelf do not fit into the exponential decreases observed in the central region. This may suggest a stronger influence of continental air masses being low in sca salt at this site.

\section{Implications for ice cores $\mathrm{B} 13$ and $\mathrm{B15}$}

In the two intermediate-depth ice cores drilled on the central Filchner-Ronne Ice Shelf, B13 (215 m deep) and B $15(320 \mathrm{~m})$, the surface trends in the chemical composition will be reflected in the corresponding depth profiles. Each core penetrated the entire layer of meteoric ice (approximately $150 \mathrm{~m}$ in both cores) and partly the marine ice (Oerter and others, 1992a, b). Both cores provide a complete record of the precipitation deposited on to the ice shelf over a time-scale estimated to be in the order of 2000 years.

Due to the fast-flowing ice shelf and according to a simple flow model after Thomas (1973), a particle path, for example, from the snow surface at BAS site 5 (the southernmost shallow firn core on the B13-B15 flowline) reaches the drill site of $B 15$ at a depth of $100 \mathrm{~m}$ and $\mathrm{B} 13$ at $105 \mathrm{~m}$, approximately. From the surface down to these depths, the concentrations will systematically decrease according to the surface-concentration gradients. For the B13 core, for example, this would give a decrease of chloride from $900 \mathrm{ppb}$ at the surface by $80 \%$ or for nss sulphate from $100 \mathrm{ppb}$ by $40 \%$, approximately. However, despite averaging over a time period of at least 20 years, there is a considerable scatter in the surface data from which the continental effects are defined. As deduced from the standard deviations of the residuals to the exponential fits, this relative scatter is estimated to be about $20 \%$ for chloride and nss sulphate, and about $30 \%$ for MSA. Apart 
from systematic errors inherent to the particle-path modelling, this ambiguity in the determin-ation of the continental effects alone will generally limit the net temporal changes which can be deduced uni-vocally along ice cores $\mathrm{B} 13$ or B15. This is particularly true for possible systematic long-term temporal trends which will most probably be obscured by the systematic surface trends unless they clearly cxceed the observed $20-30 \%$ uncertainties given above for sea salt, nss sulphate and MSA.

On the other hand, particularly the strong sea-salt gradient may be used to deduce the origin of ice found at certain depths in the ice cores (Herron and Langway, 1979). Similarly, Graf and others (1994) inferred from the stable-isotope record that the bottom part of the meteoric ise in the B13 and B15 cores most probably contains inland ice. Because typical chloride concentrations on the Antarctic plateau are always well below $100 \mathrm{ppb}$ (e.g. Kirchner and Delmas, 1988; Moslcy-Thompson and others, 1991), this ice should be marked by a significantly lower chloride concentration than the about $200 \mathrm{ppb}$ measured near the grounding line.

\section{ACKNOWLEDGEMENT}

This study was financially supported by the Deutsche Forschungsgemeinschaft (DFG).

\section{REFERENCES}

Andrar, M.O. 1986. The ocean as a source of atmospheric sulfur compounds. In Buat-Menard, P. ed. The role of ait-see exchange in grochemical oding. D. Reidel Publishing Company, 331-362.

Berresheim, H. 1987. Biogenic sulphur emissions from the sub-antarctic and antarcic occans. J. Gophes. Res., 92(T)1 1), 13,245-13,262.

Clausen, H. B. and C. C. Langway, Jr. 1989. The ionic deposits in polar ice cores. In H. Oeschger and C. C. Langway, Jr., eds. The entronmental record in glaciers and ice sheets. Dahlem Workshop Reports. John Wiley \& Sons, 225-248.

Gjessing. Y. 1984. Narine and non-marine contribution to the chemical composition of snow at the Riiser-Larsenisen Ice Shelf in Antarctica. Atmos, Entron., 18 (4), 825-830.

Gjessing. Y. 1989. Excess and deficit of sulphate in polar snow. Almos. Fimirm., $23(1 ;, 15.5-160$.

Görlach, L., 1). Wagenbach. J. Kipfstuhl, and U. Stuckenberg. 1985. Spurenstofl-glaziologische Lntersuchungen an den deutschen Antarktisstationen. In Kohnen. H., ed. Filchner-Ronne-Ice-Shelf-Programme, Repml. Vi. 2. Bremerhaven, Alfred-Wegener-Institut, 42-49.

Graf, W., H. Moser, H. Ocrter, O. Reinwarth and W. Stichler, 1988. Accumulation and ice-core studies on Filchner-Ronne Ice Shell. Antarctica. Am. Glaciol., 11, 23.31.

Graf, W. and 6 others. 1991. Isotopic and chemical investigations of $10 \mathrm{~m}$ firn cores from the eastern part of the Ronne Ice Shelf. Antarctica. In Niller, H. and H. Oerter, eds. Filchner-Ronne-Ice-Shelf-Programme: Refint Fo. 5. Bremerhaven, Alfred-Wegener-Institut, 4553.

Graf. W. and 6 others. 1994. Snow-accumulation rates and isotopic contents ${ }^{2} \mathrm{H},{ }^{3} \mathrm{H},{ }^{18} \mathrm{O}$ of near surface firn of the Filchner-Ronne Ice Sholf, Antarctica. Ann. Glaciol, 20 isee paper in this volume).

Hummer, C. U. 1980. Acidity of polar ice cores in relation to absolute dating, past volcanism, and radio echoes. .7. Giaciol, 2593, $359-372$.

Herron. M. M. 1982. Impurity souress of $\mathrm{F}, \mathrm{Cl}, \mathrm{NO}_{3}$ and $\mathrm{SO}_{4}{ }^{2}$ in Greenland and Antarctic precipitation. 7. Geoplyys. Res, 87 C4). $30.52-3060$.

Herron, M. M. and C. C. Iangway, Jr. 1979. Dating of Ross Ice Shelf cores by chemical analysis. J. Glaciol, $2490,345-3.56$.
Institut für Angewandte Goodäsic. 1987. Filcher-Romme-Shelfets. 30 Januer-14 March 1986. Glaciological map 1:2000000. Frankfurt am Main, Institut für Angewand te Geodïsie.

Kirchner, S. and R.J. Delmas. 1988. A 1000 ycar glaciochemical study at the South Pole. Amm. Glaciol. 10, 8084.

Legrand, M.R. and R.J. Delmas. 1988. Formation of HCl in the Antarctic atmospherc. 7. Gethss. Res., 93 D6:, 71537168.

Legrand, M. R. and S. Kirchner. 1990. Origins and variations of nitrate in South Polar precipitation. 7. Geophls. Res., 95 D4), 3493-3507.

Legrand, M., J.-R. Petit and Y.S. Korotkevich. 1987. D.C. ronductivity of Antarctic ice in relation to its chemistry. J. Phes. Paris. 48. Colloq. C.1, 605-611. (Supplément au 3.)

Legrand, M., C. Feniet-Saigne, L.S. Saltzman, C. Germain. N. I. Barkox and V.N. Petros. 1991. Ice-core record of oreanic cmissions of dimethylsultide during the last climate cycle. Vature. $3506314), 144-146$

Legrand, M., C. Feniet-Saigne, E. S. Saltzman and C. Germain. 1992. Spatial and temporal variations of mothancsulfonic acic and non sea salt sulfate in Antarctic ice J. Almos. Chem. 14, 245-260.

Minikin, A. 1989. Ionenchromatographische Messungen von Methansulfonsäure MSA im antarktischen Aerosol. Diplomarbcit, Institut fïr Limwelphysik, Universitut Heidelberg.)

Moore, J. C., E. W. Wolf, H. B. Clausen and C. U. Hammer. 1992. The chemical basis for the electrical stratigraphy of ice. J. Geophys. Res.. 97 (B2), $1887-1896$.

Moser, K. 1991. Raum-Zeit-Variation der chemischen Zusammensetzung des Firns antarkischer Randgebiete. Dissertation, Institut für Umweltphysik, Universität I eidelberg.

Mosler-Thompson, F., J. Dai, L. G. Thompson, P.M. Grootes. J.K. Arbogatst and J. F. Paskievitch. 1991. Glaciological studies at Siple Station Antarctical potential ice-core paleoclimatic record. 7. Glactol., 37 125$), 11-22$.

Mulianey, R., E. C. Pasteur, D. A. Peel, E.S. Saltzman and P. -Y. Whung. 1992. The ratio of MSA to non-sca-salt sulphate in Antarctic Peninsula ice cores. Tellus, 44B, 295.303.

Neubauer, J. and K. G. Heumann. 1988. Nitrate trace determination in snow and firn core samples of ice shclves at the Weddell Sea. Antarctica. Atmos. Emiron., 22(3), 537-545.

(Oerter, H. and 6 others. 1992a. Fvidence for basal marine shelf ice in the Filchner-Ronne ice shelf. Valure, 358 6385), 399-401.

Ocrter, H., C. Drücker, J. Kipfstuhl, U. Nixdorf and W. Graf. 1992b. The Filrhner IV campaign and the $320 \mathrm{~m}$ decp irs rore B15. In Oenter, H., ad. Fildmer-Ronne-Le-Shelf-Progranme, Repur io. 6. Bremerhaven, Alfred-Wegener-Institut, 47-53.

Parish, 1'. R. and D.H. Bromwich. 1991. Continental-scale simulation of the Antarctic katabatic wind regime. 7. Climale, 4, $135 \cdots 146$.

Prospero, J. M.," D. L. Savoic, E.S. Saltzman and R. Larsen. 1991. Impact of oceanic sources of biogenic sulphur acrosol concentrations at Mawson, Antarctica. Value, 350(6315), 221-223.

Pszenny, A. A., A.J. Castelle, J. N. Galloway and R. A. Duce. 1989. A study of the sulfur cycle in the antarctic marine boundary layer. J. Geophys. Res., $94 \mathrm{D} 7,9818-9830$.

Savoie, D. L., J. M. Prospero, R.J. Larsen and E. S. Saltzman. 1992. Nitrogen and sulfur species in aerosols at Matson. Antarctica. and their relationship to natural radionuclides. $J$. Itmos. Chem.. 14. $181-204$.

'Thomas, R. H. 1973. The dynamies of the Brumt Ice Shelf, Cuats Land, Antarctica. Br. Antard. Sur. Sit. Rep. 79.

Trefzer, U. 1992. Verglcich der ionischen Zusammensetzung von Aerosol- und Neuschneeproben aus dem Bereich der Georg-vonNeumayer Station, Antarktis. Diplomarbeit. Institut für Lmweltphysik, Universität Heidclberg.

Magcnbach, 1)., C. (Görlach, K. Moser and K. O. Münnich. 1988. Coastal Antarctic aerosol: the seasonal pattern of its chemical composition and radionuclide content. Tellus, 40B, 426436.

Wagenbach, D. and 6 others. 1994. Recommaissance of chemical and isotopic firn propertics on top of Berkner Island, Antarclica. Am. Glacial., 20 (see patper in this volume .

Wilson, T. R. S. 1975. Salinity and the major elements of seawater. In Riley, J. P. and G. Skirrow, eds. Chemeal Ocenographe (lat. I), 365. Zwally, H.J. 1984. Observing polar-ice variability. Anm. Glaciol. 5. $19 \mathrm{~L} 198$.

The accuracy of references in the text and in this tist is the responsibitity of the authors, to whom quevies should be addressed. 